\title{
Hubungan Faktor Predisposisi dengan Perilaku Penggunaan Alat Pelindung Diri pada Pekerja PT. Elnusa TBK Warehouse Karangampel
}

\author{
Relationship of Predisposing Factors with the Behavior of Use of Personal Protective Equipment \\ at PT. Gudang Elnusa TBK Karangampel
}

\author{
Boby Alfirdha $^{1}$, Sarinah Basri K ${ }^{2}$, Tating Nuraeni ${ }^{3}$ \\ ${ }^{1}$ Program Studi Kesehatan Masyarakat, FKM UNWIR, Indramayu \\ e-mail: *1 bobyalfirdha@gmail.com, ${ }^{2}$ b_sarinah@yahoo.com
}

\begin{abstract}
Abstrak
Alat Pelindung Diri (APD) merupakan seperangkat alat yang digunakan oleh tenaga kerja untuk melindungi seluruh atau sebagian tubuhnya terhadap kemungkinan adanya potensi bahaya kecelakaan kerja pada tempat kerja. Penggunaan Alat Pelindung Diri (APD) sebenarnya menempati prioritas pengendalian risiko paling akhir setelah pengendalian dengan eliminasi, substitusi, engeneering dan pengendalian secara administratif tidak berhasil dilakukan. Manfaat menggunakan APD saat bekerja sangat besar dalam mencegah keselamatan kerja, namun kenyataannya masih banyak pekerja yang tidak menggunakan APD dengan baik dan sesuai potensi bahaya pada saat bekerja.Jenis penelitian ini adalah penelitian observasional analitik dengan menggunakan desain cross sectional. Sampel dalam penelitian ini adalah seluruh pekerja PT. Elnusa Tbk Warehouse Karangampel sebanyak 33 orang. Analisis yang digunakan yaitu uji ChiSquare. Hasil penelitian ini menunjukkan bahwa 22 orang $(66,7 \%)$ tidak menggunakan APD, 27 orang $(81,8 \%)$ memiliki pengetahuan baik, 19 orang $(57,6 \%)$ memiliki masa kerja lama, 29 orang $(87,9 \%)$ memiliki sikap baik. Tidak terdapat hubungan antara pengetahuan, masa kerja, dan sikap dengan penggunaan APD, dengan nilai Pvalue $=0,637,0,319$, dan 1,000 . Kesimpulannya adalah tidak terdapat hubungan antara pengetahuan, masa kerja, dan sikap dengan perilaku penggunaan APD.
\end{abstract}

Kata Kunci: Pengetahuan, Masa Kerja, Sikap, Perilaku Penggunaan APD.

\footnotetext{
Abstract

Personal Protective Equipment (PPE) is a set of tools used by workers to protect all or part of his body to the possibility of the potential hazards of workplace accidents in the workplace. Use of Personal Protective Equipment (PPE) is actually the priority ultimate risk control after control by elimination, substitution, Engeneering and administrative controls are not successful. The benefits of using PPE when working enormously in preventing workplace safety, but in reality there are many workers who do not use PPE properly and according to the potential hazards at work. This research is an analytic observational study using cross sectional design. The
}

sample in this study were all employees of PT. Elnusa Warehouse Karangampel many as 33 people.The analysis used is Chi-Square test. The results showed that 22 (66.7\%) did not use PPE, 27 (81.8\%) had a good knowledge, 19 people (57.6\%) have a long working period, 29 (87.9\%) have a good attitude, 29 (87.9\%) stated that the availability of a complete PPE. There was no relationship between knowledge, years of service, and attitude with the use of PPE, with a value of $p$ value $=0.637,0.319$, and 1.000. The conclusion was that there was no correlation between knowledge, years of service, and attitude PPE usage behavior.

Keywords: Knowledge, Work Period, attitude, Behavior use of PPE.

\section{Pendahuluan}

Menghadapi era industrilisasi dan globalisasi ekonomi, penerapan keselamatan semakin penting karena merupakan bagian integral dari upaya perlindungan tenaga kerja dalam berinteraksi dengan pekerjaannya. Keberhasilan pembangunan diberbagai bidang ilmu pengetahuan dan teknologi telah meningkatkan taraf hidup kesejahteraan masyarakat. ${ }^{1}$

Keselamatan dan kesehatan kerja merupakan salah satu aspek perlindungan tenaga kerja dengan cara penerapan teknologi pengendalian segala aspek yang berpotensi membahayakan para pekerja. Banyak pekerja belum menyadari bahwa pentingnya keselamatan dan kesehatan kerja dalam melaksanakan pekerjaan. Hal ini masih terlihat dari banyaknya pekerja yang tidak menggunakan alat pelindung diri dengan lengkap, walaupun alat pelindung diri bukan satu-satunya sarana untuk menghindari 
kecelakaan kerja, namun merupakan alternatif terakhir untuk menghindari bahaya-bahaya tersebut. $^{2}$

Penggunaan Alat Pelindung Diri (APD) sebenarnya menempati prioritas pengendalian risiko paling akhir setelah pengendalian dengan eliminasi, substitusi, engeneering dan pengendalian secara administratif tidak berhasil dilakukan. Alat pelindung diri merupakan seperangkat alat yang digunakan oleh tenaga kerja untuk melindungi seluruh atau sebagian tubuhnya terhadap kemungkinan adanya potensi bahaya kecelakaan kerja pada tempat kerja. ${ }^{3}$

Berdasarkan data International Labour Organization (ILO) tahun 2013, 1 pekerja di dunia meninggal setiap 15 detik karena kecelakaan kerja dan 160 pekerja mengalami sakit akibat kerja. Tahun sebelumnya 2012 ILO mencatat angka kematian dikarenakan kecelakaan dan penyakit akibat kerja (PAK) sebanyak 2 juta kasus setiap tahun. ${ }^{4}$

Perkembangan perusahaan Minyak Bumi dan Gas (MIGAS) sangat besar di Indonesia. Potensi sumber daya minyak bumi dan gas tersebut merupakan faktor dominan dalam strategi pembangunan bangsa dan negara Indonesia. ${ }^{5}$

PT. Elnusa Tbk merupakan satu-satunya perusahaan nasional yang menguasai kompetensi di bidang jasa minyak dan gas (MIGAS) antara lain yaitu jasa seismic, pengeboran dan pengelolaan lapangan minyak. PT. Elnusa Tbk menyediakan jasa MIGAS dengan strategi aliansi global bagi perusahaan MIGAS berkelas dunia dan juga sesuai dengan standar keselamatan lingkungan.

\section{Metode Penelitian}

Penelitian ini merupakan penelitian Observasional Analitik dengan desain cross sectional. Cross sectional ialah suatu penelitian untuk mempelajari dinamika korelasi antara faktor-faktor risiko dengan efek, dengan cara pendekatan, observasi atau pengumpulan data sekaligus pada suatu saat (point time approach). ${ }^{6}$

Penelitian ini dilakukan di PT. Elnusa Tbk Warehouse Karangampel berlokasi di Jalan Raya Mundu Kecamatan Karangampel Kabupaten Indramayu. Penelitian ini dilakukan pada bulan Juli - Agustus 2018. Populasi penelitian ini adalah pekerja yang bekerja pada area red zone di PT. Elnusa Tbk warehouse karangampel sebanyak 33 pekerja.Sampel penelitian ini adalah seluruh pekerja pada area red zone di PT. Elnusa Tbk Warehouse Karangampel sebanyak 33 pekerja dengan menggunakan Total Sampling.

Analisis univariat (deskriptif) ini adalah untuk menjelaskan atau mendeskripsi karakteristik masing-masing variabel yang diteliti. Pada umumnya tujuan dari analisis univariat adalah untuk mengetahui gambaran distribusi frekuensi dan proporsi dari variabel dependen dan independen yang ada pada suatu penelitian.Analisis bivariat dilakukan untuk melihat hubungan antara variabel independen dengan dependen menggunakan uji Chi Square dengan menggunakan program Statistical Program for Social Sciences (SPSS) versi 16.0 di Laboratorium Komputer Universitas Wiralodra. Taraf signifikan yang digunakan adalah $95 \%$ atau taraf kesalahan 0,05 .

\section{Hasil}

\section{Analisis Univariat}

Analisis Univariat dalam penelitian ini meliputi variabel independen dan variabel dependen, yaitu diantaranya:Pengetahuan, Masa Kerja, Sikap dan Perilaku Penggunaan APD.

\section{Pengetahuan}

Adapun gambaran pengetahuan pada pekerja PT. Elnusa Tbk Warehouse Karangampel dapat dilihat pada tabel 1 disamping ini: 
Tabel 1 Gambaran Pengetahuan pada Pekerja PT. Elnusa Tbk Warehouse Karangampel.

\begin{tabular}{cccc}
\hline No. & Pengetahuan & N & \% \\
\hline 1 & Kurang & 6 & $18,2 \%$ \\
\hline 2 & Baik & 27 & $81,8 \%$ \\
\hline & Total & 33 & $100 \%$ \\
\hline
\end{tabular}

Berdasarkan tabel 1 diatas, dapat dilihat bahwa pengetahuan pada pekerja PT. Elnusa Tbk Warehouse Karangampel, responden yang memiliki pengetahuan kurang yaitu 6 orang $(18,2 \%)$ dan responden yang memiliki pengetahuan baik yaitu 27 orang $(81,8 \%)$.

\section{Masa Kerja}

Adapun gambaran masa kerja pada pekerja PT. Elnusa Tbk Warehouse Karangampel dapat dilihat pada tabel 2 dibawah ini:

Tabel 2 Gambaran Masa Kerja pada Pekerja PT. Elnusa Tbk Warehouse Karangampel.

\begin{tabular}{cccc}
\hline No. & Masa Kerja & $\mathbf{N}$ & $\mathbf{\%}$ \\
\hline 1 & Baru & 14 & $42,4 \%$ \\
\hline 2 & Lama & 19 & $57,6 \%$ \\
\hline & Total & 33 & $100 \%$ \\
\hline
\end{tabular}

Berdasarkan tabel 2 diatas, dapat dilihat bahwa masa kerja pada pekerja PT. Elnusa Tbk Warehouse Karangampel, responden yang memiliki masa kerja baru yaitu 14 orang $(42,4 \%)$ dan responden yang memiliki masa kerja lama yaitu 19 orang $(57,6 \%)$.

\section{Sikap}

Adapun gambaran sikap pada pekerja PT. Elnusa Tbk Warehouse Karangampel dapat dilihat pada tabel 3 disamping ini:
Tabel 3 Gambaran Sikap pada Pekerja PT. Elnusa Tbk Warehouse Karangampel.

\begin{tabular}{cccc}
\hline No. & Sikap & N & \% \\
\hline 1 & Kurang & 4 & $12,1 \%$ \\
\hline 2 & Baik & 29 & $87,9 \%$ \\
\hline & Total & 33 & $100 \%$ \\
\hline
\end{tabular}

Berdasarkan tabel 3 diatas, dapat dilihat bahwa sikap pada pekerja PT. Elnusa Tbk Warehouse Karangampel, responden yang memiliki sikap kurang 4 orang $(12,1 \%)$ dan responden yang memiliki sikap baik 29 orang $(87,9 \%)$.

\section{Perilaku Penggunaan Alat Pelindung Diri}

Adapun gambaran perilaku penggunaan APD pada pekerja PT. Elnusa Tbk Warehouse Karangampel dapat dilihat pada tabel 4 dibawah ini:

Tabel 4 Gambaran Perilaku Penggunaan Alat Pelindung Diri pada Pekerja PT. Elnusa Tbk Warehouse Karangampel.

\begin{tabular}{cccc}
\hline No. & $\begin{array}{c}\text { Perilaku } \\
\text { Penggunaan } \\
\text { APD }\end{array}$ & N & \% \\
\hline 1 & Kurang & 22 & $66,7 \%$ \\
\hline 2 & Baik & 11 & $33,3 \%$ \\
\hline & Total & 33 & $100 \%$ \\
\hline
\end{tabular}

Berdasarkan tabel 4 diatas, dapat dilihat bahwa perilaku pada pekerja PT. Elnusa Tbk Warehouse Karangampel, responden yang perilaku kurang yaitu 22 orang $(66,7 \%)$ dan responden yang perilaku baik yaitu 11 orang $(33,3 \%)$.

\section{Analisis Bivariat}

Analisis ini dilakukan untuk menguji antara masing-masing variabel meliputi hubungan antara variabel independen (bebas) dengan variabel dependen (terikat). Skala data penelitian yaitu ordinal dengan skala ordinal maka di uji statistiknya Chi- 
Square. Syarat uji Chi-Square adalah taraf signifikan yang digunakan adalah 95\% dengan nilai kemaknaan 0,05 .

Tujuan penelitian ini adalah untuk mengetahui hubungan faktor predisposisi dengan Perilaku Penggunaan APD pada Pekerja PT. Elnusa Tbk Warehouse Karangampel. Dalam hal ini analisis bivariat dilakukan dengan uji Chi-Square test menggunakan SPSS versi 16.0 hasil analisis dapat dilihat dibawah ini.

Hubungan Pengetahuan dengan Perilaku Penggunaan Alat Pelindung Diri

Adapun hasil statistik hubungan pengetahuan dengan perilaku penggunaan APD pada Pekerja PT. Elnusa Tbk Warehouse Karangampel dapat dilihat pada tabel 5 dibawah ini:

Tabel 5 Hubungan Pengetahuan dengan Perilaku Penggunaan Alat Pelindung Diri pada Pekerja PT. EInusa Tbk Warehouse Karangampel.

\begin{tabular}{|c|c|c|c|c|c|c|c|c|}
\hline \multirow{3}{*}{ No } & \multirow{3}{*}{ Pengetahuan } & \multicolumn{4}{|c|}{ Perilaku Penggunaan APD } & \multirow{2}{*}{\multicolumn{2}{|c|}{ Jumlah }} & \multirow{3}{*}{ P-value } \\
\hline & & \multicolumn{2}{|c|}{ Perilaku Kurang } & \multicolumn{2}{|c|}{ Perilaku Baik } & & & \\
\hline & & $\mathbf{N}$ & $\%$ & $\mathbf{N}$ & $\%$ & $\mathbf{N}$ & $\%$ & \\
\hline 1 & Kurang & 5 & $22,7 \%$ & 1 & $9,1 \%$ & 6 & $18,2 \%$ & \multirow{3}{*}{0,637} \\
\hline 2 & Baik & 17 & $77,3 \%$ & 10 & $90,9 \%$ & 27 & $81,8 \%$ & \\
\hline \multicolumn{2}{|c|}{ Jumlah Total \% } & 22 & $100 \%$ & 11 & $100 \%$ & 33 & $100 \%$ & \\
\hline
\end{tabular}

Berdasarkan tabel 5 hasil pengolahan data menggunakan uji statistik Chi Square dengan bantuan program SPSS diperoleh nilai ekspektasi $<5$ sehingga digunakan nilai Fisher's Exact Test yaitu didapatkan $\mathrm{P}_{\text {value }}$ sebesar 0,637 dengan nilai $\alpha=0,05$. Jadi nilai $\mathrm{P}$ value lebih besar dibanding dengan nilai $\alpha(P$ value $0,637>0,05)$, maka tidak terdapat hubungan antara pengetahuan dengan perilaku penggunaan APD pada PT. Elnusa Tbk Warehouse Karangampel.

Hubungan Masa Kerja dengan Perilaku Penggunaan Alat Pelindung Diri

Adapun hasil statistik hubungan masa kerja dengan perilaku penggunaan APD pada Pekerja PT. Elnusa Tbk Warehouse Karangampel dapat dilihat pada tabel 6 dibawah ini:

Tabel 6 Hubungan Masa Kerja dengan Perilaku Penggunaan Alat Pelindung Diri pada Pekerja PT. Elnusa Tbk Warehouse Karangampel.

\begin{tabular}{|c|c|c|c|c|c|c|c|c|}
\hline \multirow{3}{*}{ No } & \multirow{3}{*}{ Masa Kerja } & \multicolumn{4}{|c|}{ Perilaku Penggunaan APD } & \multirow{2}{*}{\multicolumn{2}{|c|}{ Jumlah }} & \multirow{3}{*}{ P-value } \\
\hline & & \multicolumn{2}{|c|}{ Perilaku Kurang } & \multicolumn{2}{|c|}{ Perilaku Baik } & & & \\
\hline & & $\mathbf{N}$ & $\%$ & $\mathbf{N}$ & $\%$ & $\mathbf{N}$ & $\%$ & \\
\hline 1 & Baru & 8 & $36,4 \%$ & 6 & $54,5 \%$ & 14 & $42,4 \%$ & \\
\hline 2 & Lama & 14 & $63,6 \%$ & 5 & $45,5 \%$ & 19 & $56,6 \%$ & 0,319 \\
\hline \multicolumn{2}{|c|}{ Jumlah Total \% } & 22 & $100 \%$ & 11 & $100 \%$ & 33 & $100 \%$ & \\
\hline
\end{tabular}


Berdasarkan tabel 6 di atas hasil pengolahan data untuk faktor predisposisi yaitu masa kerja dengan perilaku penggunaan APD diperoleh responden yang memiliki masa kerja baru dan perilaku kurang dalam penggunaan APD dengan persentase $36,4 \%$ sedangkan responden yang memiliki masa kerja lama dan perilaku baik dalam penggunaan APD dengan persentase 45,5\%.

Hasil pengolahan data menggunakan uji statistik Chi Squaredengan bantuan program SPSS didapatkan $\mathrm{P}$ value sebesar 0,319 dengan nilai $\alpha=0,05$. Jadi nilai $P$ value lebih besar dibanding dengan nilai $\alpha(\mathrm{P}$ value 0,319>0,05), maka tidak terdapat hubungan antara masa kerja dengan perilaku penggunaan APD pada PT. Elnusa Tbk Warehouse Karangampel.

\section{Hubungan Sikap dengan Perilaku Penggunaan Alat Pelindung Diri}

Adapun hasil statistik hubungan sikap dengan perilaku penggunaan APD pada Pekerja PT. Elnusa Tbk Warehouse Karangampel dapat dilihat pada tabel 6 dibawah ini:

Tabel 7 Hubungan Sikap dengan Perilaku Penggunaan Alat Pelindung Diri pada Pekerja PT. Elnusa Tbk Warehouse Karangampel.

\begin{tabular}{|c|c|c|c|c|c|c|c|c|}
\hline \multirow{3}{*}{ No } & \multirow{3}{*}{ Sikap } & \multicolumn{4}{|c|}{ Perilaku Penggunaan APD } & \multirow{2}{*}{\multicolumn{2}{|c|}{ Jumlah }} & \multirow{3}{*}{ P-value } \\
\hline & & \multicolumn{2}{|c|}{ Perilaku Kurang } & \multicolumn{2}{|c|}{ Perilaku Baik } & & & \\
\hline & & $\mathbf{N}$ & $\%$ & $\mathbf{N}$ & $\%$ & $\mathbf{N}$ & $\%$ & \\
\hline 1 & Kurang & 3 & $13,6 \%$ & 1 & $9,1 \%$ & 4 & $12,1 \%$ & \multirow{3}{*}{1,000} \\
\hline 2 & Baik & 19 & $86,4 \%$ & 10 & $90,9 \%$ & 29 & $87,9 \%$ & \\
\hline \multicolumn{2}{|c|}{ Jumlah Total \% } & 22 & $100 \%$ & 11 & $100 \%$ & 33 & $100 \%$ & \\
\hline
\end{tabular}

Berdasarkan tabel 7 di atas hasil pengolahan data untuk faktor predisposisi yaitu sikap dengan perilaku penggunaan APD diperoleh responden yang memiliki sikap kurang dan perilaku kurang dalam penggunaan APD dengan persentase $13,6 \%$ sedangkan responden yang memiliki sikap baik dan perilaku baik dalam penggunaan APD dengan persentase $90,9 \%$.

Hasil pengolahan data menggunakan uji statistik Chi Square dengan bantuan program SPSS diperoleh nilai ekspektasi <5 sehingga digunakan nilai Fisher's Exact Test yaitu didapatkan $\mathrm{P}_{\text {value }}$ sebesar 1,000 dengan nilai $\alpha$ $=0,05$. Jadi nilai $\mathrm{P}$ value lebih besar dibanding dengan nilai $\alpha\left(\mathrm{P}_{\text {value }} 1,000>0,05\right)$, maka tidak terdapat hubungan antara sikap dengan perilaku penggunaan APD pada PT. Elnusa Tbk Warehouse Karangampel.

\section{Pembahasan}

\section{Perilaku Penggunaan Alat Pelindung Diri}

Teori Lawrence Green dalam Notoatmodjo $(2014)^{7}$ mencoba menganalisis perilaku manusia yang dipengaruhi oleh dua faktor pokok, yakni faktor perilaku (behavior causes) dan faktor di luar perilaku (non- behavior causes). Perilaku itu sendiri ditentukan atau terbentuk dari tiga faktor: (a) Faktor-faktor Predisposisi (predisposing factors) yang terwujud dalam pengetahuan, sikap, kepercayaan, dan sebagainya, (b) Faktor-faktor pemungkin (enabling factors) yang terwujud dalam lingkungan fisik, tersedia atau tidak tersedianya fasilitas-fasilitas atau saranasarana, (c) Faktor-faktor pendorong atau penguat (renforcing factors) yang terwujud dalam sikap dan perilaku petugas, yang merupakan kelompok referensi dari perilaku masyarakat. 
Alat Pelindung Diri (APD) adalah peralatan keselamatan yang harus digunakan oleh pekerja apabila berada pada suatu tempat kerja yang berbahaya. APD digunakan pekerja untuk melindungi sebagian atau seluruh tubuh dari adanya potensi bahaya kecelakaan kerja. Penggunaan APD digunakan apabila usaha penanggulangan bahaya secara eliminasi, substitusi, engineering, administratif tidak maksimal dalam mengendalikan bahaya yang ada di tempat kerja.

Pengukuran perilaku dalam penelitian ini dilakukan pada pekerja PT.ElnusaTbk Warehouse Karangampel, yakni dengan melakukan pengamatan terhadap penggunaan APD dengan kategori nilai 1 untuk yang menggunakan APD $\geq 5$ yaitu artinya perilaku baik, dan nilai 0 untuk yang menggunakan

APD < 5 yaitu artinya perilaku kurang. Hasil penelitian yang dilakukan pada PT. ElnusaTbk Warehouse Karangampel menunjukkan bahwa pekerja yang tidak menggunakan APD lebih banyak yaitu 22 orang $(66,7 \%)$ daripada pekerja yang menggunakan APD yaitu 11 orang $(33,3 \%)$.

Sejalan dengan hasil penelitian Fina $(2017)^{8}$ didapatkan 43 orang $(61,4 \%)$ pekerja yang berperilaku tidak menggunakan APD saat bekerja sedangkan didapatkan 27 orang $(38,6 \%)$ pekerja yang berperilaku menggunakan APD saat bekerja dan hasil penelitian Mochammad Iqbal (2014) ${ }^{9}$ diketahui bahwa 47 responden (94\%) tidak menggunakan APD dengan lengkap, lebih banyak dari responden yang menggunakan APD dengan lengkap yaitu 3 responden $(6 \%)$.

Dari hasil penelitian ini dapat dilihat bahwa pekerja yang tidak menggunakan APD pada PT. Elnusa Tbk Warehouse Karangampel lebih banyak. Hal ini menunjukan bahwa pekerja masih kurang memiliki kesadaran terhadap upaya pencegahan dan pengendalian potensi bahaya di tempat kerja.

\section{Hubungan Pengetahuan dengan Perilaku Penggunaan Alat Pelindung Diri}

Sebagian besar pekerja memang telah memiliki pengetahuan yang baik namun dalam kenyataannya pengetahuan baik tidak menjamin pekerja patuh menggunakan APD. Tidak adanya jaminan tenaga kerja yang memiliki pengetahuan tinggi akan patuh menggunakan APD karena pengetahuan yang dimiliki pekerja hanya sampai pada pengetahuan tingkat pertama. Menurut Notoatmodjo (2003), pengetahuan tingkat pertama merupakan pengetahuan yang sekedar mengingat informasi yang diterima. Pengetahuan pekerja yang tinggi tentang APD karena pekerja hanya mengingat informasi tentang APD namun belum mencapai tingkat memahami dan mengaplikasikan penggunaan APD. ${ }^{10}$

Berdasarkan penelitian yang telah dilakukan pada pekerja PT.ElnusaTbk Warehouse Karangampeldidapatkan $\mathrm{P}$ value sebesar 1,000 dengan nilai $\alpha=0,05$. Jadi nilai $\mathrm{P}$ value lebih besar dibanding dengan nilai $\alpha(\mathrm{P}$ value $0,673>0,05)$, maka tidak terdapat hubungan antara pengetahuan dengan perilaku penggunaan APD pada pekerja PT.ElnusaTbkWarehouse Karangampel.

Hasil penelitian yang dilakukan oleh Putra $(2012)^{11}$ diketahui bahwa tidak terdapat hubungan antara pengetahuan dengan penggunaan alat pelindung diri $(\mathrm{P}$ value $=$ $0,465)$, sejalan dengan penelitian yang dilakukan oleh Hastanti (2004) ${ }^{12}$ yang menyatakan bahwa tidak ada hubungan antara pengetahuan dengan pemakaian APD, dan didukung oleh penelitian Kartika $(2014)^{13}$ yang menyatakan bahwa tidak ada hubungan antara pengetahuan dengan kepatuhan menggunakan APD $\left(\mathrm{P}_{\text {value }}=0,483\right)$.

Berdasarkan hasil penelitian yang sudah dilakukan sebelumnya dan penelitian yang sekarang, diperoleh hasil bahwa tidak terdapat hubungan antara pengetahuan dengan perilaku penggunaan APD. 
Secara teori memang disebutkan bahwa semakin tinggi tingkat pengetahuan responden tentang APD diharapkan memiliki perilaku yang sesuai ketika menggunakan APD. Pada penelitian ini menunjukkan hal yang sebaliknya, tingginya pengetahuan responden tentang APD tidak sejalan dengan perilaku penggunaan APD. Hal ini menunjukkan bahwa responden hanya mengetahui saja namun belum bisa mengaplikasikannya. Hal ini sesuai dalam teori Bloom dalam Notoatmodjo $(2003)^{10}$ yang menyatakan bahwa tingkatan pengetahuan terdiri dari tahu, paham, aplikasi, analisis, sintesis, dan evaluasi. Domain tahu hanya mengetahui tentang prinsip-prinsip APD namun belum bisa menerapkannya dalam perilaku ketika bekerja. Lebih jauh lagi Bloom juga menjelaskan bahwa perilaku tidak hanya dipengaruhi oleh pengetahuan saja (faktor predisposisi), akan tetapi dapat dipengaruhi oleh faktor pendukung dan faktor pendorong.

\section{Hubungan Masa Kerja Dengan Perilaku Penggunaan Alat Pelindung Diri}

Masa kerja merupakan salah satu faktor pada karakteristik tenaga kerja yangmembentuk perilaku. Semakin lama masakerja pekerja akan membuat pekerja lebih mengenal kondisi lingkungantempat kerja. Jika pekerja telah mengenal kondisi lingkungan tempat kerja dan bahaya pekerjaannya maka pekerja akan patuh menggunakan $\mathrm{APD}^{6}$.

Masa kerja yang berbeda antara pekerja secara umum hanya berdampak terhadap pengalamannya dalam melakukan pekerjaannya, namun biasanya bagi pekerja yang sudah lama bekerja juga ada rasa enggan memakai APD, apalagi jika selama itu dia tidak pernah mengalami kecelakaan kerja maupun penyakit akibat kerja meskipun tidak disiplin memakai APD. Hal ini sesuai dengan teori Suma'mur dalam Widyaningsih (2012) bahwa semakin lama masa kerja seseorang maka semakin besar kemungkinan seseorang untuk memahami pekerjaan seperti resiko kecelakaan kerja, namun dalam hal ini adalah berkenaan dengan kecekatan dan ketepatan serta hasil kerja yang baik dalam melakukan setiap tindakan dalam pekerjaannya bukan berkenaan dengan kebiasaan memakai $\mathrm{APD}^{14}$.

Berdasarkan penelitian yang telah dilakukan pada pekerja PT. ElnusaTbk Warehouse Karangampel didapatkan $\mathrm{P}$ value sebesar 0,319 dengan nilai $\alpha=0,05$. Jadi nilai $\mathrm{P}$ value lebih besar dibanding dengan nilai $\alpha(\mathrm{P}$ value $0,319>0,05)$, maka tidak terdapat hubungan antara masa kerja dengan perilaku penggunaan APD pada pekerja PT. Elnusa Tbk Warehouse Karangampel.

Hasil penelitian yang dilakukan oleh Kartika (2014) yang menyatakan bahwa tidak ada hubungan yang signifikan antara masa kerja dengan kepatuhan menggunakan APD (P value $=1,000){ }^{13}$, sejalan dengan penelitian yang dilakukan oleh Ahyar (2001) yang menyatakan bahwa tidak ada hubungan antara masa kerja dengan kepatuhan mengunakan $\mathrm{APD}^{15}$, dan didukung oleh penelitian Ridha (2018) yang menunjukkan bahwa tidak ada hubungan antara masa kerja dengan penggunaan alat pelindung diri $\left(\mathrm{P}_{\text {value }}=0,678\right)^{16}$.

Berdasarkan hasil penelitian yang sudah dilakukan sebelumnya dan penelitian yang sekarang, diperoleh hasil bahwa tidak terdapat hubungan antara masa kerja dengan perilaku penggunaan APD.

Pekerja dengan masa kerja baru dan masa kerja lama mempunyai tingkat pengetahuan yang berbeda, mulai dari tingkat rendah dan hingga tinggi. Hasil penelitian ini menunjukan bahwa pekerja dengan masa kerja lama mempunyai kedisiplinan yang berbeda, masih ditemukan yang tidak disiplin. Selain itu, pekerja yang belum lama bekerja di perusahaan maupun telah lama bekerja di perusahaan memiliki presentase hampir sama besar dalam perilaku penggunaan APD. Hal ini tidak hanya dilihat dari masa kerja, kemungkinan ada dari fakor lain yang ada hubungannya dengan perilaku penggunaan APD. 


\section{Hubungan Sikap dengan Perilaku Penggunaan Alat Pelindung Diri}

Sikap adalah predisposisi untuk melakukan atau tidak melakukan suatu perilaku tertentu, sehingga sikap bukan hanya kondisi internal psikologis yang murni individu, tetapi sikap lebih merupakan proses kesadaran yang bersifatnya individual. Sikap merupakan suatu kesiapan atau kesediaan untuk bertindak dan bukan merupakan suatu tindakan atau aktivitas. Suatu sikap belum otomatis dalam suatu tindakan dan untuk mewujudkan sikap menjadi suatu tindakan nyata diperlukan faktor pendukung. Sikap merupakan predisposisi evaluatif yang banyak menentukan bagaimana individu bertindak akan tetapi sikap dan tindakan nyata seringkali jauh berbeda ${ }^{17}$.

Berdasarkan penelitian yang telah dilakukan pada pekerja PT. Elnusa Tbk Warehouse Karangampel didapatkan $\mathrm{P}$ value sebesar 1,000 dengan nilai $\alpha=0,05$. Jadi nilai $\mathrm{P}$ value lebih besar dibanding dengan nilai $\alpha(\mathrm{P}$ value $1,000>0,05)$, maka tidak terdapat hubungan antara sikap dengan perilaku penggunaan APD pada PT. ElnusaTbkWarehouse Karangampel.

Hasil penelitian yang dilakukan oleh Linggasari (2008) ${ }^{18}$ didapatkan $\mathrm{P}$ value sebesar 0,06 sehingga menunjukkan bahwa tidak terdapat hubungan antara sikap dengan perilaku pekerja dalam menggunakan APD, sejalan dengan penelitian yang dilakukan Wekoyla $(2012)^{19}$, dimana tidak terdapat hubungan sikap dengan penggunaan APD dan didukung dengan penelitian Dinul $(2014)^{17}$ yang menyatakan bahwa tidak terdapat hubungan yang bermakna antara sikap dalam menggunakan alat pelindung diri $(\mathrm{P}$ value $=$ 1,000).

Dari hasil penelitian yang sudah dilakukan oleh penelitian sebelumnya dan penelitian sekarang diperoleh hasil bahwa tidak terdapat hubungan antara sikap dengan perilaku penggunaan APD pada pekerja.

Meskipun dalam penelitian ini memiliki sikap yang baik tetapi untuk perilaku penggunaan APD masih kurang. Hal ini tidak hanya dilihat dari sikap pekerja saja, kemungkinan ada dari fakor lain yang ada hubungannya dengan perilaku penggunaan APD. Sehingga tidak ada hubungan antara sikap dengan perilaku pengunaan APD.

\section{Kesimpulan}

Dari hasil penelitian yang telah dilakukan pada PT. Elnusa Tbk Warehouse Karangampel tentang Hubungan Faktor Predisposisi dengan Perilaku Penggunaan Alat Pelindung Diri, dapat ditarik beberapa kesimpulan sebagai berikut:

1. Hasil penelitian menunjukan $66,7 \%$ responden pada PT. Elnusa Tbk Warehouse Karangampel tidak menggunakan APD.

2. Hasil penelitian menunjukan $81,8 \%$ responden pada PT. Elnusa Tbk Warehouse Karangampel memiliki pengetahuan baik terkait penggunaan APD.

3. Hasil penelitian menunjukan $57,6 \%$ responden pada PT. Elnusa Tbk Warehouse Karangampel memiliki masa kerja lama.

4. Hasil penelitian menunjukan 87,9\% responden pada PT. Elnusa Tbk Warehouse Karangampel memiliki sikap baik terkait penggunaan APD.

5. Tidak terdapat hubungan antara pengetahuan dengan perilaku penggunaan APD pada pekerja PT. Elnusa Tbk Warehouse Karangampel dengan nilai $\mathrm{P}$ value $0,637>$ nilai $\alpha=0,05$.

6. Tidak terdapat hubungan antara masa kerja dengan perilaku penggunaan APD pada pekerja PT. Elnusa Tbk Warehouse Karangampel dengan nilai $\mathrm{P}$ value $0,319>$ nilai $\alpha=0,05$.

7. Tidak terdapat hubungan antara sikap dengan perilaku penggunaan APD pada pekerja PT. Elnusa Tbk Warehouse Karangampel dengan nilai $\mathrm{P}$ value $1,000>$ nilai $\alpha=0,05$. 


\section{Saran}

Penelitan ini menghasilkan kesimpulan bahwa sebagian besar pekerja memillki pengetahuan baik, sikap positif, dan masa kerja lama tentang perilaku penggunaan APD. Maka saran yang dapat diberikan yaitu diharapkan kepada pihak manager perusahaan perlu meningkatkan pengawasan terhadap perilaku penggunaan APD oleh pekerja dan hendaknya lebih tegas dalam menindak tenaga kerja yang tidak menggunakan APD secara lengkap saat bekerja, dan memberikan motivasi yang mendukung atau penghargaan bagi pekerja yang selalu menggunakan APD dengan baik dan benar. Saran lainnya adalah bagi pekerja yang telah menggunakan APD dengan baik, perlu memberikan contoh pada pekera yang lain agar seluruh pekerja dapat menggunakan APD secara lengkap sesuai dengan standar prosedur yang telah ditetapkan oleh perusahaan.

\section{Daftar Pustaka}

1. Sarini Lagata, Fauzia. 2015. Gambaran Perilaku Penggunaan Alat Pelindung Diri (APD) Pada Pekerja Di Departemen Produksi PT. Maruki Internasional Indonesia Makassar Tahun 2015. Skripsi Fakultas Kedokteran dan Ilmu Kesehatan Universitas Islam Negeri Alauddin. Makassar.

2. Dani Sucipto, Cecep. 2014. Keselamatan dan Kesehatan Kerja. Yogyakarta: Gosyen Publishing.

3. Faddila, dkk. 2016. Analisis Kepatuhan Karyawan Terhadap Penggunaan Alat Pelindung Diri (APD) Di PT. Kebon Agung Unit PG. Trangkil Pati. Jurnal Kesehatan Masyarakat Universitas Diponegoro. Semarang

4. Radita, dkk. 2015. Faktor-Faktor Yang Berhubungan Dengan Perilaku Penggunaan Alat Pelindung Diri (APD) Pada Pekerjaan Ketinggian Di PT. X.
Jurnal Kesehatan Masyarakat Universitas Diponegoro. Semarang.

5. Ramli, Soehatman. 2010. Sistem Manajemen Keselamatan dan Kesehatan Kerja OHSAS 180001. Jakarta: Dian Rakyat.

6. Notoatmodjo, Soekidjo. 2012. Metodologi Penelitian Kesehatan. Jakarta: PT Asdi Mahastya.

7. Notoatmodjo, Soekidjo. 2014. Ilmu Perilaku Kesehatan. Jakarta: PT Asdi Mahastya.

8. Sofiana, Fina. 2017. Hubungan Faktor Predisposisi Dan Faktor Pendorong Dengan Perilaku Penggunaan Alat Pelindung Dir (APD) Pada Karyawan SPBE Di Indramayu Tahun 2017. Skripsi Fakultas Kesehatan Masyarakat Universitas Wiralodra. Indramayu.

9. Iqbal, Mochammad. 2014. Gambaran Faktor-Faktor Perilaku Penggunaan Alat Pelindung Diri (APD) Pada Pekerja Di Departemen Metalforming PT. Dirgantara Indonesia (Persero) Tahun 2014. SkripsiFakultas Kedokteran dan Ilmu Kesehatan Universitas Islam Negeri Syarif Hidayatullah. Jakarta.

10. Notoatmodjo, Soekidjo. 2003. Pendidikan dan Perilaku Kesehatan. Jakarta: Rineka Cipta.

11. Putra. 2012. Hubungan Tingkat pengetahuan dan Sikap dengan Perilaku Penggunaan Alat Pelindung Diri Pada Mahasiswa Profesi Fakultas Ilmu Keperawatan Universitas Indonesia. Skripsi Fakultas Ilmu Keperawatan Program Sarjana Reguleg. Universitas Indonesia. Depok.

12. Hastanti, Rulia. 2004. Faktor Yang Berhubungan Dengan Pemakaian APD Pada Pekerja Konstruksi Bangunan. Skripsi Fakultas Kesehatan Masyarakat Universitas Airlangga. Surabaya.

13. Putri, Kartika Dyah Sertiya. 2014. Analisis Faktor Yang Berhubungan Dengan Kepatuhan Menggunakan Alat 
Pelindung Diri. Jurnal Fakultas Kesehatan Masyarakat Universitas Airlangga. Surabaya.

14. Widyaningsih. 2012. Hubungan Faktor Predisposisi dengan Implementasi Pemakaian Alat Pelindung Diri Pada Tenaga Kerja di PT. Swastama Pabelan Kartasura. Skripsi Fakultas Kedokteran Universitas Sebelas Maret. Surakarta.

15. Ahyar, M. 2001. Hubungan Karakteristik Tenaga Kerja Terhadap Pemakaian Alat Pelindung Mulut dan Hidung (Masker). Skirpsi Fakultas Kesehatan Masyarakat Universitas Airlangga. Surabaya.

16. Hayati, Ridha, Kasman, dan Raudatul Jannah. 2018. Faktor-Faktor Yang Behubungan Dengan Penggunaan Alat Pelindung Diri Pada Petani Pengguna Pestisida. Jurnal Fakultas Kesehatan Masyarakat Universitas Islam Kalimantan Banjarmasin. Banjarmasin.

17. Alhayati, Dinul Fitriani, Tuti Restuastuti, dan Fatmawati. 2014. Hubungan Pengetahuan Dan Sikap Petugas Laboratorium Patologi Dalam Menggunakan Alat Pelindung Diri Di RSUD Arifin Achmad Provinsi Riau. Jurnal Fakultas Kedokteran Universitas Riau. Riau.

18. Linggasari. 2008. Faktor-faktor yang Mempengaruhi Perilaku Penggunaan Alat Pelindung Diri di Departemen Engineering PT. Kiat Pulp \& Paper Tbk Tanggerang tahun 2008. Skripsi. Program Sarjana Kesehatan Masyarakat Universitas Indonesia. Depok.

19. Wekoyla. 2012. Hubungan Pengetahuan, Sikap, Pendidikan dan Masa Kerja Bidan Terhadap Perilaku Penggunaan Alat Pelindung Diri Pada Tindakan Pertolongan Persalinan Di Rumah Sakit Umum Provinsi Sulawesi Tenggara Dan Rumah Sakit Umum Kota Kendari Tahun 2012. Skripsi Universitas Indonesia. Depok. 